\title{
The Use of Progressives among Malaysian ESL Learners
}

\author{
Ilhamanggai Narinasamy ${ }^{1}$, Jayakaran Mukundan ${ }^{2} \&$ Vahid Nimehchisalem ${ }^{3}$ \\ ${ }^{1}$ Sekolah Menengah Kebangsaan Perimbun, Malaysia \\ ${ }^{2}$ Department of Language and Humanities Education, Faculty of Educational Studies, University Putra Malaysia, \\ Malaysia \\ ${ }^{3}$ Faculty of Languages and Linguistics, University Malaya, Malaysia \\ Correspondence: Ilhamanggai Narinasamy, Sekolah Menengah Kebangsaan Perimbun, KM16, Jalan Cheras, \\ 43200, Selangor Darul Ehsan, Malaysia. Tel: 60-18-399-1040. E-mail: ilhajega22@hotmail.com
}

$\begin{aligned} & \text { Received: August 26, } 2013 \\ & \text { Accepted: September 15, } 2013 \quad \text { Online Published: October 10, } 2013 \\ & \text { doi:10.5539/elt.v6n11p39 }\end{aligned}$ URL: http://dx.doi.org/10.5539/elt.v6n11p39

\begin{abstract}
Studies on ESL/EFL learners' use of the progressives reveal that it is one of the grammatical aspects most problematic to them. This paper presents the results of a study on the use of progressives among Year 5, Form 1 and Form 4 Malaysian ESL learners' compositions using the English of Malaysian School Students (EMAS) corpus. The purpose of this study is to investigate if the progressives do pose any difficulties to Malaysian ESL learners. The results showed that the use of progressives increase in frequency in tandem with the educational levels of the ESL learners, indicating there is an ongoing development in language learnt. The frequency count of progressives in the 'Picture-Based' essay was higher by $74.25 \%$ compared to 'The Happiest Day of My Life' essay. It was also found that the past progressives were used more than the present progressives across levels. These findings might be connected to the genre of the essays written. The findings may have useful implications for English language teachers in preparation to teach the progressives more effectively; syllabus designers to look into efficient ways to incorporate progressives into the curriculum; and material developers to produce helpful resources in aiding language teachers' attempts in explaining this troublesome grammar construction.
\end{abstract}

Keywords: corpus linguistics, progressives, learner corpus, narrative essays, descriptive essays, ESL/EFL learners

\section{Introduction}

Progressives are also known as the expanded form, expanded tense, the continuous tense, the temporary aspect, the periphrastic form, and the progressives aspect (Romer, 2005). All these are based on the form TO BE + the present participle of a verb, such as are dancing. Progressives are used with the present, past and perfect tenses; modals, lexical modals; and passives.

Most Europeans, Africans and Asians find the English progressives one of the problematic forms to understand (Swan and Smith, 2001). Therefore, it is not surprising that the accurate use of the English progressives have been often been considered as one of the most difficult grammar items to be grasped for second language learners of the English language (Ranta, 2006). This is also true for the Malaysians second language learners of English (ESL).

Malaysia being a multi-ethnic population uses the Malay language as the national language while the English language is the second language. However, the other languages used by the other ethnic groups are used in their specific language medium schools (known as 'National-type schools') and communities such as Tamil by the Indians and Mandarin by the Chinese. This has resulted in the lack of opportunity to acquire the English language in a natural setting; therefore, formal instruction in the classroom has become the main source of learning the language in a limited time. Secondary school ESL learners have a contact of approximately 5 hours per week with the language in the classroom (Arshad \& Hawanum, 2011).

In the Malay and Chinese languages, the verbs are not marked for persons, tense, number or auxiliary elements to indicate tense and aspect, making it difficult even for the most proficient Malay and Chinese speakers to master the complexity of the English verb system (Janet, 2001). English verbs change based on the aspect of time but in Malay and Chinese languages the verbs remain the same in the present, past, future and progressive 
tenses (Saadiyah and Khor, 2009). For example, the Malay language expresses the progressives with sedang / semasa / sewaktu / sementara with a verb to describe an on-going action or event (Janet, 2001). Hence, a proficient Malay language user may use the English progressives as an equivalent but tend to drop the auxiliary such as:

They eating their dinner tonight

They coming back late tomorrow (Yong, 2001)

However, in the Tamil language, not all sentences have subject, verb and object. A complete sentence may have only a verb or only a subject and object. The syntactical differences between the Tamil and English languages such as the absence of verbs to be in the Tamil language may hinder ESL learners to construct correct progressives, for example, Peter is doing his homework may be written as Peter doing his homework because the word order in Tamil (Peter - homework - doing) does not have the verb to be is (Maniam, 2010).

Therefore, it is not surprising that Malaysian ESL learners may struggle to grasp the use of progressives in their written and verbal tasks as Ranta (2006) asserts that the difficulty in learning progressives is due to the differences between the English language and the learner's mother tongue or first language She further explains that if the progressive forms are missing or used differently from their mother tongue/first language, the ESL learners would be unable to use or form the progressives properly. Thus, it is important to delve into previous examination on the use of progressives among ESL learners.

\section{Literature Review}

Several studies are available on the English language learners' use of progressives. However, Ayoun and Salaberry (2008) indicate that only a few studies on the progressives have been carried out in the second or foreign language context and there is a need to do further investigations. The use of progressives is definitely more difficult than the simple form of the verb for learners of English as a Foreign Language (EFL) (Bald, Carstensen and Hellinger, 1972 cited in Romer, 2005). Zydati $\beta$ (1976) found that this form "is certainly one of the elements within the English language whose syntax and semantics have remained rather elusive concepts for most learners of English as a foreign language" (p. 352). Zydatiß's analysis of the spoken and written data in his corpus analysis found $50 \%$ ( 77 errors out of 154 attempts) of inappropriate use of the progressive by ESL German learners because these students do not understand the context and aspect in which the progressive is used. This is further proven when $26 \%$ of progressive errors occur in the discursive category while $74 \%$ in the narrative category in the form of retold or free essays (Zydati $\beta, 1976)$.

Johansson and Stavestrand's (1987) study on Norwegian EFL learners' problems with the use of the progressive obtained similar results as Zydatiß (1976). They found that the 15 and 16 year olds Norwegian learners who had studied English for six years tend to overuse the progressives in their written work at the ratio of $7.2 \%$. These learners either under-used or overused the progressive as it is a new concept to German and Scandinavian EFL learners because there is no such form in these languages (Johansson \& Stavestrand, 1987). In several other studies, learners' errors in certain structures in their L2 have been attributed to the non-existence of such structures in their native languages (cf. Klein, 1995; Lenko-Szymanska, 2004, Zydati $\beta$, 1976). Even Polish EFL learners find difficulties in understanding the past progressive forms due to the different ways progressives are used in Polish and English (Smith, 1988). For example, verbs expressing on-going events are imperfective in Polish but progressive in English (Smith, 1988).

The examples below are indications of the existing problems regarding the proper use of progressives (Romer, 2005; Wulff \& Romer, 2009).

1) We saw the Houses of Parliament and we saw Big Ben. Most people are thinking [think] that the tower's name is Big Ben but Big Ben is only the name of the bell.

2) What are you doing [do you do] every day?

3) Two years later Grace expected [was expecting] our first son, Philip.

Several studies carried out in the Malaysian ESL context have shown that the progressives are a problem for ESL learners just as other ESL learners around the world. Rosli and Edwin (1989) carried out a study to classify and evaluate the types of errors found in Form Four learners' English Language compositions from two urban and two rural secondary schools in the state of Selangor Darul Ehsan. However, only one Form Four class from each school was randomly selected. These selected learners were allowed to write their composition on any topic to better enable them to express themselves and also asked questions when in doubt. Rosli and Edwin (1989) analyzed 80 scripts ( $31.2 \%$ of the sample) and found Form 4 ESL learners have a high percentage of errors in the 
use of the present progressive tense $(67 \%)$ and the past progressive tense $(75 \%)$. There was also no evidence of the present perfect progressive tense in their written samples even though it is found in the syllabus. There were also no instances of the future progressives, future prefect progressives and the past perfect progressives. This may be due to the reason that no reference on these tenses is made in the syllabus (Rosli \& Edwin, 1989).

Learners from national type Chinese schools in Malaysia committed many errors in the progressives as they tend to over-generalize and perceive that the simple past tense, past progressive tense, present perfect and past perfect could be used interchangeably (Abdul Rashid Mohamed, Goh, Li Lian \& Wan Rose Eliza, 2004). Abdul Rashid Mohamed et al. (2004) carried out a research on 305 Malaysian Chinese ESL learners' errors from a national type Chinese school in Penang in an English narrative written in response to the topic, The Day that Everything Went Wrong. They found that many of the learners wrote "... a big and foolish dog was slept ..." instead of was sleeping. Saadiyah and Khor (2009) discover similar results in a research they carried out among 70 Form 1 learners from a national type Chinese school in Perak writing a composition about their family. They attributed their results to the fact that there is no such concept as present, past, future and progressive tense in the Chinese and Malay language (Saadiyah \& Khor, 2009).

In a corpus study carried out by Arshad and Hawanum (2011) using the Malaysian School Students (EMAS) corpus on the use of the auxiliary be among Primary 5 Malaysian ESL learners, they found when these learners attempted to use the progressive in their writing, they made mistakes. Their study looked into sentences from two corpus sets. The first set was a collection of oral and written language of primary 5, Form 2 and Form 4 learners in 2000 while set two was a collection of smaller scale version of set one of the same language tasks and educational levels in 2007. Only the primary 5 learners and the narrative essay entitled "The Happiest Day of My Life" were used from both sets. Their research revealed that these young learners omitted the co-referent noun phrase but retained the auxiliary be. Another common mistake found was when they made an effort to construct a complex sentence, they failed to include a relative pronoun (e.g., who) therefore resulting in errors. The complex sentence I saw a kid struggling in the river would have been grammatically correct if the relative pronoun was used, I saw a kid who was struggling in the river (Arshad \& Hawanum, 2011). If practitioners do not come up with strategies to help learners grasps the concept of the progressives, these learners will continue to commit such errors even when they embark into tertiary education.

Ting, Mahanita and Chang (2010) carried out a research to investigate the grammatical errors found in spoken English of University learners who are less proficient in the English for Social Purposes (ESP) course. The oral data was obtained from 42 learners in 126 simulated interactions from role-play situations in the 50-hour ESP course. These 42 learners had obtained Bands 1 to 3 in their Malaysian University English Test (MUET).The oral data were transcribed and analyzed for grammatical errors using the surface structure taxonomy of Dulay, Burt and Krashen (1982). The common type of tense error observed among university students is using the base form of the verb in place of the progressive tense such as I'm not cancel the birthday party when it should have been I'm not cancelling the birthday party in the spoken form among university learners (Ting, Mahanita, Chang, 2010). These learners tend to get confused with the use of present, past, and future progressive tenses in various contexts.

From what has been discussed so far, it can be inferred that EFL/ESL learners have problems using progressives correctly. In the Malaysian ESL learners context more than 20 years have passed since Rosli and Edwin's study in 1989 and little has changed based on their, as well as Arshad and Hawanum's (2011), findings.

\section{Method}

\subsection{Population and Sampling}

This corpus-based study investigates the ways in which progressives are used in the present, past, present perfect and past perfect tense by Malaysian ESL learners based on the EMAS corpus. In the data file of the EMAS corpus (Arshad et al., 2002), there are three written pieces composed by Year 5, Form 1 and Form 4 ESL learners. Only two essays and three levels will be used in this study. Only two essays will be used due to the topic and the nature of how the essays were written. The first essay, a 'Picture-Based' essay (Appendix A), was carried out in schools under the supervision of the researchers from the EMAS corpus. The next essay, 'The Happiest Day of My Life' (Appendix B), was written under the supervision of the students' own school teachers. The third essay was selected from students' homework, based on a free topic. Since there is a tendency that this third essay may have been tutored by the students' teachers as it was done as their homework the present researchers decided to exclude it.

As there are more than 1500 essays in the 'Picture-Based' and 'The Happiest Day of My Life' essays, a study is required to identify the number and types of progressives that are produced in these essays. Table 1 illustrates the 
number of essays written by Year 5, Form 1 and Form 4 learners for the topic 'The Happiest Day of My Life' and a 'Picture-Based' prompt. The total number of essays for the topic 'The Happiest Day of My Life' was 646 and 'Picture-Based' was 859.

Table 1. Frequency of progressives used in by Year 5, Form 1, and Form 4 learners in 'The Happiest Day of My Life' and 'Picture-Based' Essays (Arshad et al., 2002)

\begin{tabular}{lllll}
\hline Essay & Year 5 & Form 1 & Form 4 & Total \\
\hline Happiest Day of My Life & 270 & 219 & 157 & 646 \\
Picture-Based & 294 & 301 & 264 & 859 \\
\hline
\end{tabular}

From the total of 1,505 essays $(646+859), 90$ were selected for this study. Forty-five essays from 'The Happiest Day of My Life' (15 essays each from Year 5, Form1 and Form 4) and 45 essays from 'Picture-Based' (15 essays each from Year 5, Form1 and Form 4) were chosen. According to the related literature, a sample size of between 10 and 30 was used for similar studies (Hill, 1998). However, Hertzog (2008) recommended a sample size of between 10 and 15 per group is adequate for a feasibility study. Therefore, the researchers decided to use fifteen essays per level for this study. Purposive sampling was employed where the first two to three essays per school were chosen so that the findings from the study would represent the corpus. Purposive sampling is another type of non-probability sampling, which is characterized by the use of judgment and a deliberate effort to obtain representative samples by including typical areas or groups in the sample (Kerlinger, 1986).

\subsection{Detailed Analysis of Data}

A simple outline was then designed using Microsoft Word (Appendix C) to enable the researchers to analyze the data. The first column represents the school code, the topic ( $\mathrm{H}$ for 'The Happiest Day of My Life' essays; and $\mathrm{P}$ for 'Picture-Based' essays), the level, (F1 for Form 1 and F4 for Form 4) and the respondent (01, 02 etc.). The essay of the respondent is in the second column. The third column is for the researcher to mark the errors and make any suitable notation which is done manually. The findings of the study will be discussed in the following section.

\section{Findings}

For each form of progressives that was used, absolute occurrences were manually calculated on the selected population. Table 2 shows the number of attempts the Year 5 learners used progressives in their essays. There were only 28 attempts, with merely 3 attempts in 'The Happiest Day of My Life' essays. Progressives were used more in the 'Picture-Based' essays with 25 attempts. This means that there were considerably more progressives in the 'Picture-Based' essays (89.29\%) than in 'The Happiest Day of My Life' essays. Furthermore, all the attempts in using progressives were erroneous in 'The Happiest Day of My Life' essays. The correct use of progressives in the 'Picture-Based' essays was $52 \%$ of the total number of attempts.

Table 2. Frequency of progressives used in 'Picture-Based' and 'The Happiest Day of My Life' essays among Year 5 learners

\begin{tabular}{llllll}
\hline Progressive Form & \multicolumn{2}{l}{ Error Free } & \multicolumn{2}{l}{ Error Laden } & \multicolumn{2}{l}{ Total } \\
\hline & HD & PB & HD & PB & \\
am + V ing & - & - & 1 & - & 1 \\
are + V ing & - & - & - & 8 & 8 \\
is + V ing & - & - & - & 1 & 1 \\
was + V ing & - & 3 & 1 & 1 & 5 \\
were + V ing & - & 10 & 1 & 2 & 13 \\
has been + V ing & - & - & - & - & - \\
have been + V ing & - & - & - & - & - \\
had been + V ing & - & - & - & - & - \\
TOTAL & - & 13 & 3 & 12 & 28 \\
PERCENTAGE & - & $46.43 \%$ & $10.71 \%$ & $42.86 \%$ & $100 \%$ \\
\hline
\end{tabular}

HD - 'Happiest Day of My Life' essay

PB - 'Picture-Based' essay 
Table 3 shows the number of attempts the Form 1 learners used progressives in the two essays. There was an increase of $62.67 \%$ in the use of progressives from Year 5 to Form 1. There were only 7 instances where the Form 1 learners used the progressives for 'The Happiest Day of My Life' essays compared to 37 attempts in the 'Picture-Based' essays. In the 'Picture-Based' essays the learners used progressives considerably more frequently $(84.09 \%)$ than in 'The Happiest Day of My Life' essays. Additionally, only $50 \%$ of the progressives used by the learners in the 'Picture-Based' essays were correct.

Table 3. Frequency of progressives used in 'Picture-Based' and 'The Happiest Day of My Life' essays among Form 1 learners

\begin{tabular}{llllll}
\hline Progressive Form & Error Free & \multicolumn{3}{l}{ Error Laden } & Total \\
& HD & PB & HD & PB & \\
\hline am + V ing & - & - & 1 & - & 1 \\
are + V ing & - & 1 & - & 8 & 9 \\
is + V ing & - & - & - & 2 & 2 \\
was + V ing & 2 & 9 & - & 8 & 19 \\
were + V ing & 2 & 10 & 1 & 2 & 15 \\
has been + V ing & - & - & - & - & - \\
have been + V ing & - & - & - & - & - \\
had been + V ing & 1 & - & - & - & 1 \\
TOTAL & 5 & 20 & 2 & 20 & 47 \\
PERCENTAGE & $10.63 \%$ & $42.55 \%$ & $4.26 \%$ & $42.55 \%$ & $100 \%$ \\
\hline
\end{tabular}

HD - 'Happiest Day of My Life' essay

PB - 'Picture-Based' essay

Table 4. Frequency of progressives used in 'Picture-Based' and 'The Happiest Day of My Life' essays among Form 4 learners

\begin{tabular}{llllll}
\hline Progressive Form & Error Free & \multicolumn{2}{l}{ Error Laden } & Total \\
& HD & PB & HD & PB & \\
\hline am + V ing & 3 & 1 & 3 & - & 7 \\
are + V ing & 1 & - & - & 4 & 4 \\
is + V ing & 3 & - & 3 & 3 & 10 \\
was + V ing & 8 & 8 & 2 & 14 & 32 \\
were + V ing & 2 & 19 & 5 & 10 & 36 \\
has been + V ing & - & - & 1 & - & 1 \\
have been + V ing & 2 & - & - & - & 2 \\
had been + V ing & - & - & - & - & - \\
TOTAL & 19 & 28 & 14 & 31 & 92 \\
PERCENTAGE & $20.65 \%$ & $30.44 \%$ & $15.22 \%$ & $33.69 \%$ & $100 \%$ \\
HD - 'Happiest Day of My Life' essay & & & & &
\end{tabular}

Table 4 shows the number of attempts the Form 4 learners made to use progressives in their essays. There were 33 attempts of using progressives in 'The Happiest Day of My Life' essays compared to 59 attempts in the 'Picture-Based' essay. The learners had used more progressives in the 'Picture-Based' essays than 'The Happiest Day of My Life' essays.

\section{Discussion}

The study revealed that the Malaysian ESL learners do use progressives in their writing but they are limited to only one type of progressives, namely, the past progressive. Year 5 ESL learners' erroneous attempts in using progressives in their essays especially in 'The Happiest Day of My Life' essays mean that they may have problems understanding and using the progressive. This study also found that Form 1 learners used more 
progressives by $62.67 \%$ in comparison to Year 5 learners. This is an indication that language development has taken place. The $50 \%$ accuracy in the use of progressives by Form 1 ESL learners indicates that for every other attempt to use progressives, the learners committed an error. It could therefore be concluded that the learners had not fully mastered how to use the progressives correctly. The indication of language development is further seen when there is an increase of $66.19 \%$ use of progressives in Form 4 compared to Form 1. However, only nearly half of the attempts of using the progressive were correct (47.46\%), indicating that even the Form 4 learners were not well versed in using progressives correctly. The results also found that the Picture based essays have more usage of the progressives than the Happiest Day of My Life essays regardless of the ESL learners' levels. There were far fewer progressives in 'The Happiest Day of My Life' essays compared to the 'Picture-Based' essays. The former topic may not have provided opportunities for the learners to use progressives as compared to the latter essay. Table 5 shows the accumulative count of progressives in both essays written by the Year 5, Form 1 and Form 4 ESL learners. These ESL learners' attempts to use progressives show that their attempts were only $50 \%$ accurate.

Table 5. The accumulative count of progressive use in 'Picture-Based' and 'The Happiest Day of My Life' essays among Year 5, Form 1 and Form 4 learners

\begin{tabular}{llll}
\hline Progressive Form & Error Free & Error Laden & Total \\
\hline am + V ing & 4 & 5 & 9 \\
are + V ing & 2 & 18 & 20 \\
is + V ing & 3 & 10 & 13 \\
was + V ing & 30 & 27 & 57 \\
were + V ing & 43 & 21 & 64 \\
has been + V ing & - & 1 & 1 \\
have been + V ing & 2 & - & 2 \\
had been + V ing & 1 & - & 1 \\
TOTAL & 85 & 82 & 167 \\
PERCENTAGE & $50.90 \%$ & $49.10 \%$ & $100 \%$ \\
\hline
\end{tabular}

It is essential to compare these findings to other empirical findings to reveal if any differences or similarities are found. Table 6 displays the distribution of progressives patterns found in studies by Ota (1963), Joos (1994), Allen (1966), Romer (1995) and Collins (2009). Ota's findings differed from those of Joo's and Allen's findings due to the nature of their corpus. Ota's corpus was taken from the spoken American English data while Joos and Allen's corpora were based on the written forms of British English and American English respectively. However, Romer's findings are similar to that of Ota's because her corpus was the combined spoken components of the British National Corpus (BNC) and The Bank of English (BoE) corpus. Collins (2008) corpus was from the written and spoken components of the International Corpus of English (ICE) of Great Britain, Australia, New Zealand, Philippines, Singapore, Hong Kong, India and Kenya. Based on all these studies, the researchers' study on the use of progressives by Malaysian ESL learners show that Malaysian learners are more inclined to use past progressives than present progressives. The nature of the tasks that the learners did for the corpus may be one of the reasons for this outcome. The written tasks which was descriptive (The Happiest Day of My Life) and narrative (Picture-Based) in nature required these ESL learners to use the past progressives more than the present progressives.

Table 6. Comparison of the progressive forms distribution in empirical studies to EMAS corpus

\begin{tabular}{lcccc}
\hline Studies & $\begin{array}{c}\text { Present } \\
\text { Progressives }\end{array}$ & Past Progressives & $\begin{array}{c}\text { Present Perfect } \\
\text { Progressives }\end{array}$ & $\begin{array}{c}\text { Past Perfect } \\
\text { Progressives }\end{array}$ \\
\hline Ota (1963) & $76.60 \%$ & $15.47 \%$ & $7.53 \%$ & $0.57 \%$ \\
Joos (1964) & $47.01 \%$ & $45.97 \%$ & $4.42 \%$ & $2.60 \%$ \\
Allen (1966) & $48.00 \%$ & $40.00 \%$ & $6.29 \%$ & $5.71 \%$ \\
Romer (1995) & $69.36 \%$ & $26.29 \%$ & $3.70 \%$ & $0.65 \%$ \\
Collins (2008) & $54.30 \%$ & $32.30 \%$ & $3.60 \%$ & $1.10 \%$ \\
Narinasamy et. al (2013) & $25.15 \%$ & $72.46 \%$ & $1.80 \%$ & $0.60 \%$ \\
\hline
\end{tabular}


The frequency findings of the present and past progressives by Biber, Leech and Conrad's (1999:462) in spoken and written data illustrate the present progressives forms were used frequently compared to the past progressives forms. However, these findings have no definite figures. Instead Biber et.al (1999) provided a diagram as shown in Figure 1.

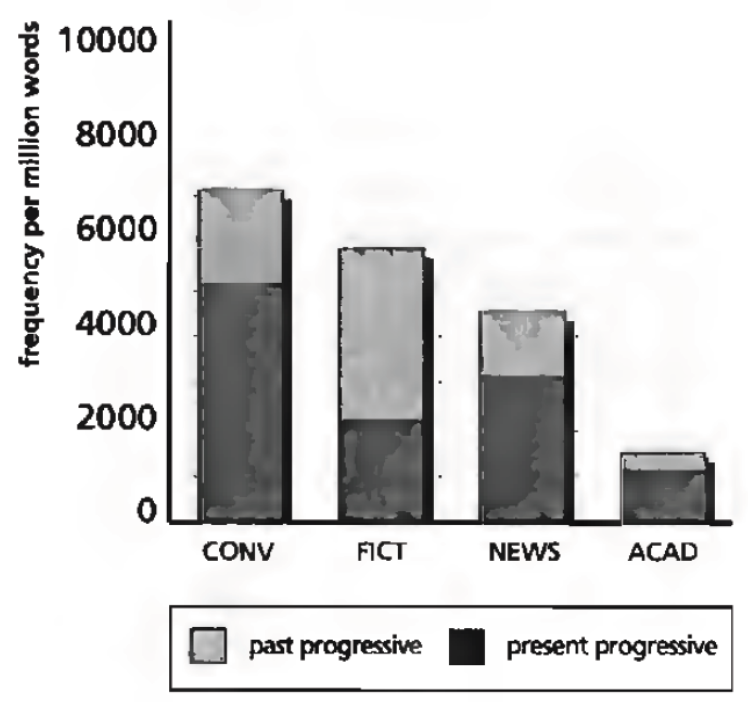

Figure 1. Frequency of past progressive and present progressive cross registers (Biber et al, 1999:462)

The present progressives were used more than the past progressives in the conversation, news and academic registers, as shown in Figure 1. Nonetheless, the past progressives were used more frequently in the fiction register, which is similar to the researchers' findings from the EMAS corpus. The fiction subcopora showed about $60-70 \%$ usage of past progressives, which is quite similar to the findings of the researchers $(72.46 \%)$. As mentioned earlier, the learners tended to use the past progressive more frequently than the other progressives. Therefore, the syllabus and curriculum specifications were looked into to understand this outcome.

The progressive emphasized in the Integrated Primary School Curriculum syllabus (Kurikulum Bersepadu Sekolah Rendah) for the primary school is the present continuous tense, past continuous tense and future continuous tense. The curriculum specifications of Year 1 to Year 6 show that only in Year 5 are learners introduced to the present progressive to indicate actions and this is reinforced in Year 6. However, there is no indication of the past progressive in the curriculum specifications at all. The Integrated Secondary School Curriculum syllabus (Kurikulum Bersepadu Sekolah Menengah) for the secondary school emphasized the continuous tense under the verb category. The curriculum specification of Form 1 and Form 4 also emphasize the present continuous tense. Surprisingly most of the Year 5, Form 1 and Form 4 learners did not apply what they had learnt in writing the essays. The past prefect progressive and the present perfect progressive were the least frequent types of progressives used by the learners. The reason could be that these tenses are not highlighted in the curriculum but one or two learners tried using them, thus indicating that there may be learners who may learn beyond what their respective curricula have prescribed to be taught to them. Another possibility is that learners may have applied what they have learnt in passives to construct the past or present perfect progressive. Further investigation using the EMAS corpus is required to enable better understanding of these initial findings.

\section{Conclusions}

A number of conclusions can be made based on the present findings that will be presented in this section. Reportedly, grammar instruction in the ESL/EFL classroom can yield significant results in proficiency and explicit grammar teaching can be more effective than implicit grammar teaching (Cowan, 2008). When rules are explained or sample sentences that represent the rules are shown, it has a better and longer-lasting effect (Noonan, 2004; Norris \& Ortega, 2000). However, practitioners must be aware that these explicitly learnt rules may not guarantee that learners will not commit any errors while writing their essays as they may not have the time to comprehend the rules.

The implicit knowledge of grammar is greatly effective in speaking activities if these rules have been 
internalized. This is the way an L1 learner uses the language effortlessly, as the learner subconsciously applies accurate grammar rules and uses grammatically correct utterances based on his or her implicit knowledge. ESL learners, on the other hand, would need to figure out the explicit grammar rules learnt and attempt to apply these in their writing tasks. However, when they are speaking, errors may still occur as they do not have the time to think of the rules (Noonan, 2004).

The results from the study showed an increase in the frequency of progressive use among Year 5, Form 1 and Form 4 learners indicating that there is development in the language learnt and at the same time producing more language input to be used for analysis. The frequency count of progressives in the 'Picture-Based' essay was higher by $74.25 \%$ compared to 'The Happiest Day of My Life' essay. This difference may indicate that progressives tend to be used more frequently in the 'Picture-Based' prompts. However, a more in-depth study with a larger sample is necessary before this finding can be generalized. Future studies should be conducted to investigate the way progressives are presented in the primary and secondary textbooks and on why certain types of progressives are used more frequently by the learners than others.

Corpus-based studies on progressives especially in EFL contexts have contributed very much to the teaching and learning of English. However, in the Malaysian ESL context, there are very limited corpus-driven studies on progressives. Corpus studies on progressives need to be carried out to add to the body of knowledge as the progressive is one of the problematic concepts for the ESL/EFL learners and therefore must be taken seriously and studied more systematically.

\section{References}

Abdul Halim Ibrahim, \& Mariam Mohamed Nor. (2006). Grammar for ESL Teachers. Tanjung Malim: Penerbitan Profesional Baharu.

Abdul Rashid Mohamed, Goh, Li Lian, \& Wan Rose Eliza. (2004). English Errors and Chinese Learners. Sunway College Journal, 1, 83-97.

Allen, R. L. (1966). The Verb System of the Present-day American English. The Hague: Mouton.

Arshad Abdul Samad, \& Hawanum Hussein. (2011). Teaching Grammar and What Student Errors in the Use of the English Auxiliary 'be' Can Tell Us. The English Teacher, 34, 164-178.

Arshad, A. S., Fauziah, H., Mukundan, J., Ghazali, K., Sharifah, Z., Juridah, R., \& Edwin, M. V. (2002). English of Malaysian School Students (EMAS) corpus. Serdang: Universiti Putra Malaysia Press.

Ayoun, D., \& Salaberry, R. (2008). The expression of temporality in English as a foreign language by French native speakers. Language Learning, 58(3), 555-595. http://dx.doi.org/10.1111/j.1467-9922.2008.00450.x

Biber, D., Johansson, S., Leech, G., Conrad, S., \& Finegan, E. (1999). Longman Grammar of Spoken and Written English. London: Longman.

Collins, P. (2008). The Progressive Aspect in World Englishes: A Corpus-based Study. Australian Journal of Linguistics, 28(2), 225-249. http://dx.doi.org/10.1080/07268600802308782

Cowan, R. (2008). The Teacher's Grammar of English: A course book and reference guide. Cambridge: Cambridge University Press.

Duan, M. (2011). A Corpus-based Study of the Misuse of Tense in the English Composition of Chinese College Students. English Language Teaching, 4(4), 173-180. http://dx.doi.org/10.5539/elt.v4n4p173

Hertzog, M. A. (2008). Considerations in determining sample size for pilot studies. Research in Nursing \& Health, 31, 180-191. http://dx.doi.org/10.1002/nur.20247

Hill, R. (1998). What sample size is "enough" in internet survey research? Interpersonal Computing and Technology: An Electronic Journal for the 21 $1^{\text {st }}$ Century, 6(3/4). Retrieved April 22, 2012, from http://www.emoderators.com/ipct-j/1998/n3-4/hill.html\#roscoe

Johansson, S., \& Stavestrand, H. (1987). Problems in learning and teaching the progressive form. In Lindblad, I., \& Ljung M. (Eds.), Proceedings from the Third Nordic Conference for English Studies, Hasselby, Sept 25 -27, 1986 (vol. 1, pp. 139-148). Stockholm: Almquist \& Wiksell.

Joos, M. (1964). The English Verb, Form and Meanings. Madison: The Univeristy of Wisconsin Press.

Kerlinger, Fred N. (1986). Foundations of behavioral research (3rd ed.). New York: Holt, Rinehart and Winston.

Klein, E. (1995). A simplest analysis of the English tense-aspect system. In Riehle, W., \& Keiper, H. (Eds.), Anglistentag 1994 Graz: Proceedings (pp. 139-151). Tubingen. Neimeyer. 
Lenko-Szymanska, A. (2004). Past Progressive or Simple Past? The acquisition of the progressive aspect by Polish advanced learners of English. Paper presented at the $6^{\text {th }}$ Teaching and Language Corpora conference (TaLC 6), Ganada, July 6-9, 2004.

Malaysia, Ministry of Education. (2000). Kurrikulum Bersepadu Sekolah Menengah Syllabus. Kuala Lumpur: Curriculum Development Centre.

Malaysia, Ministry of Education. (2001). Kurrikulum Baru Sekolah Rendah Syllabus. Kuala Lumpur: Curriculum Development Centre.

Malaysia, Ministry of Education. (2003). Curriculum specifications for English language form 1. Kuala Lumpur: Curriculum Development Centre.

Malaysia, Ministry of Education. (2003). Curriculum specifications for English language form 2. Kuala Lumpur: Curriculum Development Centre.

Malaysia, Ministry of Education. (2003). Curriculum specifications for English language form 3. Kuala Lumpur: Curriculum Development Centre.

Malaysia, Ministry of Education. (2003). Curriculum specifications for English language form 4. Kuala Lumpur: Curriculum Development Centre.

Malaysia, Ministry of Education. (2003). Curriculum specifications for English language form 5. Kuala Lumpur: Curriculum Development Centre.

Malaysia, Ministry of Education. (2003). Curriculum specifications for English language year 2.Kuala Lumpur: Curriculum Development Centre.

Malaysia, Ministry of Education. (2003). Curriculum specifications for English language year 3. Kuala Lumpur: Curriculum Development Centre.

Malaysia, Ministry of Education. (2003). Curriculum specifications for English language year 4. Kuala Lumpur: Curriculum Development Centre.

Malaysia, Ministry of Education. (2003). Curriculum specifications for English language year 5. Kuala Lumpur: Curriculum Development Centre.

Malaysia, Ministry of Education. (2003).Curriculum specifications for English language year 1. Kuala Lumpur: Curriculum Development Centre.

Malaysia, Ministry of Education. (2004). Curriculum specifications for English language year 6. Kuala Lumpur: Curriculum Development Centre.

Noonan III, Francis J. (2004). Teaching ESL students to "Notice" Grammar. Internet TESL Journal, 10(7). Retrieved April 22, 2012, from http//iteslj.org/Techniques/Noonan-Noticing.html

Norris, J., \& Ortega, L. (2000). Effectiveness of L2 instruction: A research synthesis and quantitative meta-analysis. Language Learning, 50, 417-428. http://dx.doi.org/10.1111/0023-8333.00136

Ota, A. (1963). Tense and aspect in Present-day American English. Tokyo: Kenkyusha.

Ranta, E. (2006). The 'Attractive' Progressive - Why use the -ing Form in English as a Lingua Franca? Nordic Journal of English Studies, 5(2), 95-116.

Romer, U. (2005). Progressives, Patterns, Pedagogy: A corpus-driven approach to English progressive forms, functions, contexts and didactics. Amsterdam: John Benjamin's Publishing Company.

Rosli Talif, \& Edwin, M. (1989). Error Analysis of Form Four English Compositions. The English Teacher, 18, $110-124$.

Saadiyah Darus, \& Khor, H. C. (2009). Common Errors in Written English Essays of Form One Chinese Students: A Case Study. European Journal of Social Sciences, 10(2), 242-253.

Sharwood Smith, M. (1988). Imperative versus progressive: An exercise in contrastive pedagogical linguistics. In Rutherford, \& Sharwood Smith, M. (Eds.), Grammar and second language teaching (pp. 224-230). New York: Newbury House.

Smith, N. (2002). Ever moving on? The progressive in recent Britisah English. In Peters, P., Collins, \& Smith, A. (Eds.), New Frontiers in Corpus Research (pp. 317-330). Amsterdam: John Benjamin's Publishing Company.

Ting, S. H., Mahanita Mahadhir, \& Chang, S. L. (2010). Grammatical Errors in Spoken English of University 
Students in Oral. GEMA Online TM Journal of Language Studies, 10(1), 53-70.

Wulff, S., \& Romer, U. (2009). Becoming a proficient academic writer: Shifting lexical preferences in the use of the progressive. Corpora, 4(2), 115-133. http://dx.doi.org/10.3366/E1749503209000276

Yong, J. Y. (2001). Malay/Indonesian Speakers. In Swan, B., \& Smith, B. (Eds.), Learner English: A Teacher's Guide to Interference and other Problems (vol. 1, pp. 279-295). Cambridge: Cambridge University Press.

Zydati $\beta$, W. (1976). Learning problem expanded form: A performance analysis. IRAL, 14, 351-371. http://dx.doi.org/10.1515/iral.1976.14.4.351

\section{Copyrights}

Copyright for this article is retained by the author(s), with first publication rights granted to the journal.

This is an open-access article distributed under the terms and conditions of the Creative Commons Attribution license (http://creativecommons.org/licenses/by/3.0/). 